\title{
Sonolysis and Sonoacidification of Ultrasonic Disintegration of Excess Sludge
}

\begin{abstract}
E. ZIELEWICZ
Institute of Water and Wastewater Engineering, Silesian University of Technology Konarskiego 18, 44-100 Gliwice, Poland

The expected effect of ultrasonic disintegration of excess sludge is particle dispergation and cell lysis i.e. the elimination of sludge microorganisms and the release of the contents of dead cells into the sludge liquid which results in an increase in chemical oxygen demand. Sonolysis also formed the basis for the intensification of volatile fatty acids production during the acid fermentation of excess sludge treated ultrasonically. In this study the investigations into the direct effects of excess sludge ultrasonic treatment revealed an increase in volatile fatty acid concentration directly (without fermentation process) after the ultrasonic treatment which is closely related to sonolysis.
\end{abstract}

PACS numbers: $43.35 .-\mathrm{c}$

\section{The direct and technological effects of ultrasonic disintegration}

A sequence of sonochemical and biochemical changes initiated in an ultrasonic field forms the basis for the introduction of ultrasonic disintegration techniques to intensify the stabilization of sludge resulting from municipal sewage treatment. The main expected effect of ultrasonic disintegration of excess sludge is cell lysis (sonolysis) i.e. the elimination of sludge microorganisms and the release of the contents of dead cells into the sludge liquid which results in an increase in chemical oxygen demand (COD) of the substances dissolved in the liquid [1-3]. Sonolysis was also connected with other effect of ultrasonic disintegration defined as the dispergation of sludge particles (sonodispergation). This effect could be described by changes of dewaterability of sludge. The changes in the filtration properties of the sludge have also been investigated since they are directly related to the dispergation of the solid phase of the sludge [4] and were examined with capillary suction time (CST) test.

The ultrasonic lysis (sonolysis) and dispergation (sonodispergation) of microorganism cells is the direct effect of disintegration, however, its technological 
effect involves the intensification of the first hydrolytic phase of the multistage methane fermentation of sludge. Sonolysis also formed the basis for the intensification of volatile fatty acids (VFAs) production during the acid phase of fermentation of excess sludge treated ultrasonically. VFAs, notably $\mathrm{CH}_{3} \mathrm{COOH}$, perform an important role in the biological treatment of sewage because they constitute the main source of easily accessible organic carbon for the microorganisms that eliminate biogenic compounds from it. It has been found that the initial ultrasonic treatment of sludge prior to fermentation (maintaining suitable process parameters [5-7]) causes a 100-400\% increase in VFAs produced during the acidic stage of fermentation.

In this study the investigations into the direct effects of excess sludge ultrasonic treatment revealed an increase in VFA concentration directly after the ultrasonic treatment which is closely related to sonolysis. This effect has not been discussed in the literature so far, therefore, it has been defined (by author of [8]) as sonoacidification herein and distinguished from sonolysis.

\section{Experimental procedures and result}

The investigation have been realized in the laboratory scale. The excess sludge from municipal sewage treatment plant $\mathrm{Z}$ has been disintegrated with the disintegrator WK-2000, at power of $450 \mathrm{~W}$ and frequency at $23 \mathrm{kHz}$ or with ultrasonic washer OL-My-1, at power of $90 \mathrm{~W}$ and frequency at $25 \mathrm{kHz}$. In the course of investigation some characteristics of sludge have been changed. Some tests were carried out on the excess sludge (mechanically thickened with polyelectrolyte on the technical scale thickening to concentration $6.1 \%$ of dry mass) which was prepared prior to ultrasonic disintegration so that the structure of the suspensions could be altered thus changing its susceptibility to disintegration.

The sludge was prepared in three ways employing:

- coagulation with Zetag 7861 polyelectrolyte $\left(100 \mathrm{mg} / \mathrm{dm}^{3}\right)$ or

- aeration of a $1 \mathrm{dm}^{3}$ sample with compressed air at $6 \mathrm{dm}^{3} / \mathrm{min}$ for $30 \mathrm{~min}$, or

- homogenization i.e. stirring with a $1000 \mathrm{~W}$ homogenizing laboratory stirrer for $3 \mathrm{~min}$ (power consumption of $5 \mathrm{Wh} / \mathrm{dm}^{3}$ ).

The sludge thus prepared was treated ultrasonically with ultrasonic washer OL-My-1 at a generated power consumption of $\mathrm{EG}=20 \mathrm{kWh} / \mathrm{m}^{3}$.

\subsection{The indicators of the direct effects of ultrasonic disintegration}

The changes in COD provided the basis for monitoring and assessment of disintegration effectiveness expressed by sonolysis indicator $-k d 1$ following the formula:

$$
k d 1=C O D u t / C O D u u,
$$

where $C O D u t \rightarrow$ COD of the substances dissolved in ultrasonically treated sludge 
liquid $\left(\mathrm{mg} \mathrm{O} \mathrm{O}_{2} / \mathrm{dm}^{3}\right)$, CODuu $\rightarrow$ COD of the substances dissolved in sludge liquid untreated ultrasonically $\left(\mathrm{mg} \mathrm{O}_{2} / \mathrm{dm}^{3}\right)$.

The effect of ultrasonic change of part of hydrolyzed organic substance to short-chain carboxylic acids, defined as sonoacidification was described by the sonoacidification indicator - $k d 2$ and expressed as

$$
k d 2=V F A u t / V F A u u,
$$

where VFAut $\rightarrow$ VFA concentration in ultrasonically treated sludge $\left(\mathrm{mg} \mathrm{CH}_{3} \mathrm{COOH} / \mathrm{dm}^{3}\right)$, VFAuu $\rightarrow$ VFA concentration in sludge untreated ultrasonically $\left(\mathrm{mg} \mathrm{CH}{ }_{3} \mathrm{COOH} / \mathrm{dm}^{3}\right)$.

Changes in dispergation brought about by ultrasonic treatment were described by an indicator of dewaterability changes and called sonodispergation indicator $k d 3$ :

$$
k d 3=\text { CSTut } / \text { CSTuu, }
$$

where CSTut $\rightarrow$ CST of ultrasonically treated sludge (s); CSTuu $\rightarrow$ CST of untreated sludge ( $\mathrm{s}$ ).

Since the final ultrasonic treatment effects expressed by the indicators $k d 1$, $k d 2$ and $k d 3$ depended on the properties of the sludge resulting from preliminary preparation, additional indicators that described the overall effect of the preliminary preparation and ultrasonic disintegration were also defined. They were as follows:

- $k d 1(c)=\operatorname{CODut}(c) / C O D u u$ - indicator of sonolysis of coagulated sludge,

$-k d 1(a)=\operatorname{CODut}(a) / C O D u u-$ indicator of sonolysis of aerated sludge,

- $k d 1(h)=C O D u t(h) / C O D u u$ - indicator of sonolysis of homogenized sludge,

- $k d 2(c)=\operatorname{VFAut}(c) / V F A u u$ - indicator of sonoacidification of coagulated sludge,

- $k d 2(a)=\operatorname{VFAut}(a) / V F A u u$ - indicator of sonoacidification of aerated sludge,

- $k d 2(h)=V F A u t(h) / V F A u u-$ indicator of sonoacidification of homogenized sludge,

- $k d 3(c)=C S T u t(c) / C S T u u-$ indicator of sonodispergation of coagulated sludge,

- $k d 3(a)=\operatorname{CSTut}(a) / C S T u u$ - indicator of sonodispergation of aerated sludge,

$-k d 3(h)=\operatorname{CSTut}(h) / C S T u u-$ indicator of sonodispergation of homogenized sludge.

\subsection{Results and discussion}

The influence of dry matter concentration in not preliminarily prepared excess sludge on direct effects of ultrasonic disintegration are presented in Table I. 
The effects of ultrasonic field on the preliminarily prepared sludge are given in Table II. In this table here are presented both kinds of effects - changes of COD, VFA and CST as the influence of preliminary preparation and changes in effects of disintegration (disintegration indicators as above) as the consequences of preparation. The values of the indicator in both tables show that sonolysis and sonoacidification depended on dry matter of sludge as well as on the methods of preliminary preparation, but not in the same way. The best sonolysis was obtained at $2.7 \% \mathrm{~d} . \mathrm{m}$. (dry mass), the best sonoacidification at $2.5 \% \mathrm{~d} . \mathrm{m}$. and the best sonodispersion at $1.5 \%$ (Table I). Generally, the direct effects of ultrasound disintegration were worse at very low and very high concentration of dry mass. In the technical scale, on sewage treatment plants, the high concentration (above 4\%) of excess sludge is receiving at mechanical thickeners and it is advantage before sludge digestion. For that, to improve its susceptibility on ultrasonic disintegration the preliminary preparation was applied.

TABLE I

The influence of dry matter concentration on the effects of soluble COD and VFAs production and particle dispergation in sludge sonicated with disintegrator WK-2000.

\begin{tabular}{|c|c|c|c|c|c|c|c|c|c|}
\hline \multirow{4}{*}{$\begin{array}{l}\text { Symbol of } \\
\text { excess } \\
\text { sludge } \\
{[\% \text { of } \mathrm{d} . \mathrm{m} .]}\end{array}$} & \multicolumn{9}{|c|}{ Indicator of ultrasonic disintegration process } \\
\hline & \multicolumn{3}{|c|}{ sonolysis } & \multicolumn{3}{|c|}{ sonoacidification } & \multicolumn{3}{|c|}{ sonodispergation } \\
\hline & CODuu & CUDut & \multirow[t]{2}{*}{$k d 1$} & VFAuu & VFAut & \multirow[t]{2}{*}{$k d 2$} & \multirow{2}{*}{$\begin{array}{c}C S T u u \\
{[\mathrm{~s}]}\end{array}$} & \multirow{2}{*}{$\begin{array}{c}\text { CSTut } \\
{[\mathrm{s}]}\end{array}$} & \multirow[t]{2}{*}{$k d 3$} \\
\hline & {$\left[\mathrm{mgO}_{2}\right.$} & $\left./ \mathrm{dm}^{3}\right]$ & & {$[\mathrm{mg} /$} & $\left.\mathrm{dm}^{3}\right]$ & & & & \\
\hline $\mathrm{Z}(0.8)$ & 160 & 240 & 1.5 & 80 & 91 & 1.1 & 56 & 62 & 1.1 \\
\hline $\mathrm{Z}^{*}(1.5)$ & 60 & 140 & 2.3 & 34 & 96 & 2.8 & 40 & 95 & 2.4 \\
\hline $\mathrm{Z}^{*}(2.5)$ & 142 & 360 & 2.5 & 42 & 163 & 3.9 & 33 & 45 & 1.4 \\
\hline $\mathrm{Z}^{*}(2.7)$ & 223 & 646 & 2.9 & 60 & 120 & 2.0 & 80 & 99 & 1.2 \\
\hline $\mathrm{Z}^{* *}(4.5)$ & 110 & 180 & 1.6 & 60 & 134 & 2.2 & 32 & 56 & 1.8 \\
\hline $\mathrm{Z}^{*}(5.3)$ & 157 & 291 & 1.9 & 48 & 120 & 2.5 & 81 & 92 & 1.1 \\
\hline
\end{tabular}

${ }^{*}$ thickened without polyelectrolyte; ${ }^{* *}$ thickened with polyelectrolyte

Analysis of the results in Table II indicates that the preliminary preparation brought about changes in sonolysis effects and changes in sonoacidification effects as well as in sonodispergation effects. Out of the three techniques used, intensive stirring with air (aeration) or homogenizing stirrer considerably improved the effects of sonolysis shown by a twofold increase in sonolysis indicators $k d 1(a)$ and $k d 1(h)$ compared to indicator $k d 1$ for the unprepared sludge. As for coagulation, it caused a decrease in sonolysis indicator $k d 1(c)<k d 1$. Those effects might be connected with the increase or decrease in the dispergation of sludge particles expressed by the indicators of CST. Aeration and homogenization caused an instantaneous increase in CST and subsequently an over twofold increase in sonodispergation indicator $k d 3(a)$ and threefold increase in indicator $k d 3(h)$ compared to $k d 3$ of the unprepared sludge. The deterioration of the effects of sonodispersion and sonolysis in coagulated sludge is related to the reduced occurrence of ultrasonic cavitation in the water containing polyelectrolyte [9]. All the tests re- 
TABLE II

The influence of preparation on the effects of soluble COD, VFAs production and particle dispergation in sludge sonicated with washer OL-My-1.

\begin{tabular}{|c|c|c|c|c|c|c|c|c|c|}
\hline \multirow{3}{*}{$\begin{array}{c}\text { Methods of } \\
\text { preparation of } \\
\text { excess sludge } \\
(6.1 \% \text { of dry } \\
\text { mass })\end{array}$} & \multicolumn{9}{|c|}{ Indicators of ultrasonic disintegration process } \\
\hline & \multicolumn{3}{|c|}{ sonolysis } & \multicolumn{3}{|c|}{ sonoacidification } & \multicolumn{3}{|c|}{ sonodispergation } \\
\hline & $\begin{array}{l}\text { CODuu } \\
\quad \text { or } \\
C O D u t \\
{\left[\frac{\mathrm{mgO}_{2}}{\mathrm{dm}^{3}}\right]}\end{array}$ & $k d 1$ & $\begin{array}{l}\mathrm{kd} 1(\mathrm{c}) \\
k d 1(a) \\
k d 1(h)\end{array}$ & $\begin{array}{c}V F A u u \\
\text { or } \\
V F A u t \\
{\left[\mathrm{mg} / \mathrm{dm}^{3}\right]}\end{array}$ & $k d 2$ & $\begin{array}{l}k d 2(c) \\
k d 2(a) \\
k d 2(h)\end{array}$ & $\begin{array}{l}\text { CSKuu } \\
\text { or } \\
C S K u t \\
\text { [s] }\end{array}$ & $k d 3$ & $\begin{array}{l}\mathrm{kd} 3(\mathrm{c}) \\
k d 3(a) \\
k d 3(h)\end{array}$ \\
\hline $\begin{array}{c}\text { no preparated } \\
\text { no sonicated }\end{array}$ & 297 & & & 65 & & & 158 & & \\
\hline $\begin{array}{c}\text { no preparated } \\
\text { sonicated }\end{array}$ & 2022 & 6.8 & & 106 & 1.6 & & 885 & 5.6 & \\
\hline $\begin{array}{c}\text { coagulated } \\
\text { no sonicated }\end{array}$ & 135 & & & 28 & & & 74 & & \\
\hline $\begin{array}{l}\text { Coagulated (C) } \\
\text { and sonicated }\end{array}$ & 1860 & 12.8 & 6.3 & 220 & 7.9 & 3.4 & 673 & 9.1 & 4.2 \\
\hline $\begin{array}{c}\text { aerated no } \\
\text { sonicated }\end{array}$ & 256 & & & 94 & & & 232 & & \\
\hline $\begin{array}{c}\text { aerated }(\mathrm{A}) \\
\text { and sonicated }\end{array}$ & 3477 & 12.6 & 11.7 & 236 & 2.4 & 3.6 & 2006 & 8.7 & 12.7 \\
\hline $\begin{array}{c}\text { homogenized } \\
\text { no sonicated }\end{array}$ & 714 & & & 214 & & & 740 & & \\
\hline $\begin{array}{c}\text { homogenized }(\mathrm{H}) \\
\text { and sonicated }\end{array}$ & 3019 & 3.2 & 10.2 & 246 & 1.2 & 3.8 & 2874 & 3.9 & 18.2 \\
\hline
\end{tabular}

vealed that the preliminary preparation enhanced the effects of sonoacidification, not only $k d 2(a)>k d 2$ and $k d 2(h)>k d 2$ but also $k d 2(c)>k d 2$. This may indicate that the increase in volatile fatty acids in the liquid of ultrasonically treated sludge, although correlated with sonolysis (VFA is part of COD which is proved by acidification degree $\eta=\mathrm{VFA} / \mathrm{COD}$ ), does not correspond precisely to the increase in COD. The effect of sonoacidification is also much less dependent on the dispergation of sludge particles which was much compared to the sonolysis effect.

The quantity and quality of $V F A u t$ produced was connected with cell lysis, however, a simple regression correlation between the sonolysis indicator $k d 1$ and the increase in sonoacidification indicator $k d 2$ did not occur since not all high indicators of the VFA increase were conditioned by high sonolysis indicators [8].

Since simple organic acids were the expected technological product of ultrasonic disintegration, the fact that their increased concentrations resulted from the ultrasonic treatment itself, prior to fermentation, acts as an incentive to investigate the processes resulting from the activity of an ultrasonic field.

The study has revealed that the effects of ultrasonic waves on organic substances, notably living ones, present in excess sludge are enormously diverse and still unknown. The wide variety of phenomena that result from the activity of the ultrasonic field should distinguish it from other techniques of mechanical disintegration. 


\section{Conclusion}

1. The effects of disintegration depend on dry matter of sludge as well as on the method of preliminarily preparating the sludge.

2. The rank of increase in sonolysis is not the same as of sonoacidification. Flocculation have caused decrease in sonolysis and dispergation but increased sonoacidification; on the contrary, aeration as well as homogenization have caused increase in all describing effects.

3. The investigation showed that more beneficial disintegration could be obtained for the sludge which were preliminarily homogenized.

4. The quantity and quality of VFAut produced (sonoacidification) was connected with cell lysis, however, a simple regression correlation between the sonolysis indicator $k d 1$ and the increase in sonoacidification indicator $k d 2$ did not occur since not all high indicators of the VFA increase were conditioned by high sonolysis indicators.

\section{References}

[1] F. Hogan, Water Wastew. Int. 18, 35 (2003).

[2] A. Grönroos, H. Kyllönnen, K. Korpijärvi, P. Pirkonen, T. Paavola, J. Jokela, J. Rintala, Ultrasonic Sonochem. 12, 115 (2005).

[3] E. Zielewicz-Madej, MQ Acoustic J. 21, 319 (2000).

[4] J. Guan, J. Amalr, T. Waite, Water Sci. Technol. 47, 255 (2003).

[5] Y.-C. Chiu, C.-N. Chang, S.-J. Huang, Water Sci. Technol. 36, 155 (1997).

[6] E. Zielewicz-Madej, Eng. Environmental Protection (Czestochowa) 6, 455 (2003) (in Polish).

[7] E. Zielewicz-Madej, MQ Acoustic J. 26, 299 (2005).

[8] E. Zielewicz, Ultrasonic Disintegration of Excess Sludge to Produce Volatile Fatty Acids, Silesian University of Technology, Gliwice, Poland 2007 (in Polish).

[9] K. Wójs, Cavitation in liquids of various rheological properties, TU, Wrocław 2004 (in Polish). 